\title{
GALLSTONES IN CHILDREN WITH SICKLE CELL DISEASE FOLLOWED UP AT A BRAZILIAN HEMATOLOGY CENTER
}

\author{
Ana Paula dos Santos GUMIERO ${ }^{1}$, Maria Angela BELLOMO-BRANDÃ ${ }^{1,2}$, \\ Elizete Aparecida Lomazi da COSTA-PINT01
}

\begin{abstract}
Background - Sickle cell disease causes chronic and recurrent hemolysis which is a recognized risk factor for cholelithiasis. This complication occurs in $50 \%$ of adults with sickle cell disease. Surgery is the consensual therapy for symptomatic patients, but the surgical approach is still controversial in asymptomatic individuals. Aims - To determine the frequency and to describe and discuss the outcome of children with sickle cell disease complicated with gallstones followed up at a tertiary pediatric hematology center. Methods - In a retrospective and descriptive study, 225 charts were reviewed and data regarding patient outcome were recorded. Results - The prevalence of cholelithiasis was $45 \%$ and half the patients were asymptomatic. The mean age at the time of diagnosis of cholelithiasis and surgical treatment was 12.5 years (standard deviation $=5$ ) and 14 years (standard deviation $=5.4$ ), respectively. The prevalence of cholelithiasis was higher in patients with SS homozygous and S $\beta$ heterozygous thalassemia when compared to patients with sickle cell disease. In $50 \%$ of symptomatic patients, recurrent abdominal pain was the single or predominant symptom. Thirty-nine of 44 patients submitted to surgery reported symptom relief after the surgical procedure. Asymptomatic individuals who did not undergo surgical treatment were followed up for 7 years (standard deviation $=4.8$ ), and none of them presented complications related to cholelithiasis during this period. Conclusions The frequency of cholelithiasis in the study population was $45 \%$. One-third of the patients were diagnosed before 10 years of age. Patients with the SS homozygous or S $\beta$ heterozygous phenotype were at a higher risk for the development of cholelithiasis than patients with sickle cell disease. About $50 \%$ of patients with gallstones were asymptomatic, the most of them did not undergo surgery and did not present complications during a 7-year follow-up period. Cholecystectomy must be considered in symptomatic patients. In asymptomatic patients, conservative management seems to be the better choice.
\end{abstract}

HEADINGS - Cholelithiasis. Hemoglobin SC disease. Cholecystectomy. Child.

\section{INTRODUCTION}

Sickle cell disease (SCD) is a congenital condition of universal distribution and its most common clinical manifestation is anemia due to chronic hemolysis. Persistent and accelerated hemolysis associated with multiple transfusions is a recognized risk factor for the development of cholelithiasis. The occurrence of gallstones is one of the most important manifestations of SCD in the digestive $\operatorname{tract}^{(1,3,11,12,13)}$. Increased unconjugated bilirubin excretion, bilirubin precipitation and the growth of bilirubinate crystals are determinant factors for the formation of gallstones. Most gallstones are pigmented and characteristically occur at younger ages when compared to cholesterol stones. The prevalence of cholelithiasis is high in patients with SCD and increases progressively with age, affecting $50 \%$ of young adults ${ }^{(1,4,12)}$.

Cholelithiasis mainly occurs after the age of 5 and is directly related to the severity of SCD and to the intensity of hemolysis. Some patients with gallstones report abdominal pain, whereas others might be asymptomatic. The diagnosis is confirmed by routine ultrasonographic examination.

The medical literature and guidelines are unanimous in indicating cholecystectomy for symptomatic patients ${ }^{(5)}$, but controversy still exists regarding the appropriate treatment for asymptomatic or oligosymptomatic SCD patients with cholelithiasis. Although a low complication rate has been reported in some studies, suggesting an expectant conduct ${ }^{(6,12)}$, others have proposed elective surgery

\footnotetext{
Department of Pediatrics, Division of Pediatric Gastroenterology, Division of Pediatric Hematology, Department of Child Health, Faculty of Medicine, Campinas State University (UNICAMP). Center of Hematological Investigation, Centro Infantil Domingos Boldrini

${ }^{1}$ Department of Pediatrics, Faculty of Medicine, Campinas State University; ${ }^{2}$ Centro Infantil Boldrini, Campinas, SP.

Correspondence: Dr. Ana Paula S. Gumiero - Rua Emilio Perino, 360 - Jd. Parque Avenida. 13482-248 - Limeira, SP. E-mail: aninha75@uol.com.br
} 
because of lower mortality and fewer surgical complications compared to an emergency surgery or procedure after an acute cholecystitis episode ${ }^{(2,10)}$.

Considering specific demographic aspects such as haplotype variety, socioeconomic conditions and access to medical facilities, we found it necessary to determine the prevalence of cholelithiasis in Brazilian patients with SCD. The objective of the present study was to determine the frequency of gallstones in children with SCD treated at a Pediatric Hematology Center in Brazil selected according to age and type of hemoglobinopathy, and to describe the follow-up and outcome after the diagnosis of cholelithiasis.

\section{METHODS}

A retrospective and descriptive study was performed by reviewing medical charts of patients followed between March of 1978 and October of 2003, according to a previously tested study protocol, including pertinent variables. The charts were reviewed by a single observer.

The ideal sample size was calculated based on the number of sickle cell patients seen at hospital "Centro Infantil Boldrini", Campinas, SP, Brazil, and on the prevalence of cholelithiasis in the age groups studied according to data described in the medical literature. Patients were randomly selected in alphabetical order from a list provided by the statistics department of the hospital.

Patients included in the study had their diagnosis confirmed by hemoglobin electrophoresis and presented at least one ultrasonographic exam in their charts. The SPSS for Windows software, version 11.0 (SPSS, Inc., Chicago, IL, USA) was used for analysis of the data. Descriptive analysis consisted of allocating continuous variables for position and dispersion and arranging categorical variables in frequency tables. The chi-square or Fisher's exact test was used to determine associations or to compare proportions. A level of significance of 5\% was adopted.

The study protocol was approved by the Ethics Committee on Research of "Centro Infantil Boldrini", with no need for informed consent of the patients or their parents since the study was retrospective and based on chart review.

\section{RESULTS}

A total of 225 charts from SCD patients for whom at least one abdominal ultrasound was available were reviewed. The sample included $120(53.3 \%)$ males. SCD was diagnosed at a mean age of 3 years $(S D=3.1$, range: 1 month to 13 years, median: 1.5 years). The mean age of the patients at the time of chart review was 16.8 years $(\mathrm{SD}=0.9$, range: 7 months to 33.2 years, median: 16.6 years), and $83 \%(187 / 225)$ of the children were older than 10 years. Homozygous sickle cell disease (SS) was present in 143 patients (63.5\%), sickle cell-hemoglobin C disease (SC) in 44 (19.6\%), and heterozygous sickle cell disease/ beta-thalassemia $(\mathrm{S} \beta)$ in $38(16.9 \%)$.

The overall frequency of cholelithiasis was 45\% (101/225) and was higher in patients with SS and S $\beta$ disease (Table 1).
Considering each type of hemoglobinopathy alone, the prevalence of cholelithiasis was higher in SS patients when compared to SC or Sß disease $(P=0.0044)$. SS and S 3 , when considered as a single group, presented a higher prevalence of cholelithiasis than the SC group $(P=0.001)$ (Figure 1).

TABLE 1. Overall frequency of gallstones and frequency according to the type of hemoglobinopathy

\begin{tabular}{lcccc}
\hline Hemoglobin $(\mathrm{Hb})$ type & $\mathrm{n}$ & $\%$ & Diagnosis of gallstones $(\mathrm{n})$ & $\%$ \\
\hline $\mathrm{SS}$ & 143 & 63.6 & 72 & 50.3 \\
$\mathrm{~S} \beta$ & 38 & 16.9 & 19 & 50.0 \\
$\mathrm{SC}$ & 44 & 19.6 & 10 & 22.7 \\
Total & 225 & 100 & 101 & 44.9 \\
\hline
\end{tabular}

$\mathrm{Hb} S \mathrm{~S}=$ sickle cell disease

$\mathrm{Hb} \mathrm{SB}=\mathrm{SB}$ thalassemic

$\mathrm{Hb} \mathrm{SC}=\mathrm{SC}$ disease

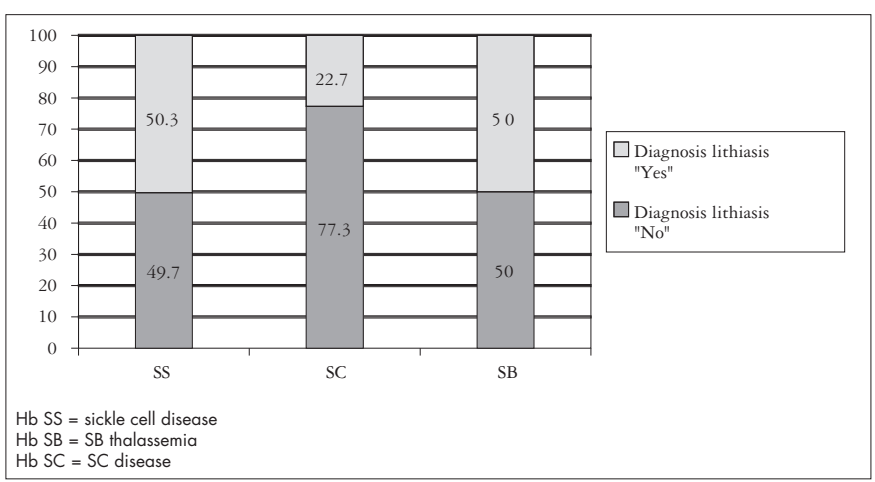

FIGURE 1. Percentage of the diagnosis of cholelithiasis in different types of sickle cell disease

The mean age at the diagnosis of cholelithiasis was 12.5 years ( $\mathrm{SD}=5$, range: 4 to 30 years, median: 13 years), with no significant difference between genders $(P=0.191)$ or in terms of age at the diagnosis of $\operatorname{SCD}(P=0.24)$. Among 101 patients with cholelithiasis, 88 had multiple stones and 12 patients had one single gallstone.

The frequency of gallstones increased with age, with the condition being diagnosed before the age of 5 in $6.9 \%$, between 5 and 10 years of age in $26.7 \%$, between 10 and 15 years in $37.6 \%$, between 15 and 20 years in $21.8 \%$, and after 20 years of age in $6.9 \%$ (Figure 2). Considering the distribution of cumulative percentage of gallstone diagnosis, this rise in incidence risk occurs after the age of 10 years, and stabilizes before 20 years of age (Figure 3).

Fourteen patients were symptomatic at the time of diagnosis of cholelithiasis and 34 became symptomatic during follow-up, for a total of 48 symptomatic patients. Symptoms included nonspecific abdominal pain, abdominal pain located in the right hypochondrium, rich-food intolerance, nausea and emesis after meals, jaundice worsening or choluria, and fever (Table 2). Sixteen in 45 patients with abdominal pain related location of pain in right hypochondrium and 13/45 referred abdominal pain as cramp. Differential diagnosis with vaso-occlusive crises was not possible in $25 \%$ of patients with cholelithiasis and nonspecific or diffuse abdominal pain (Table 3 ). 


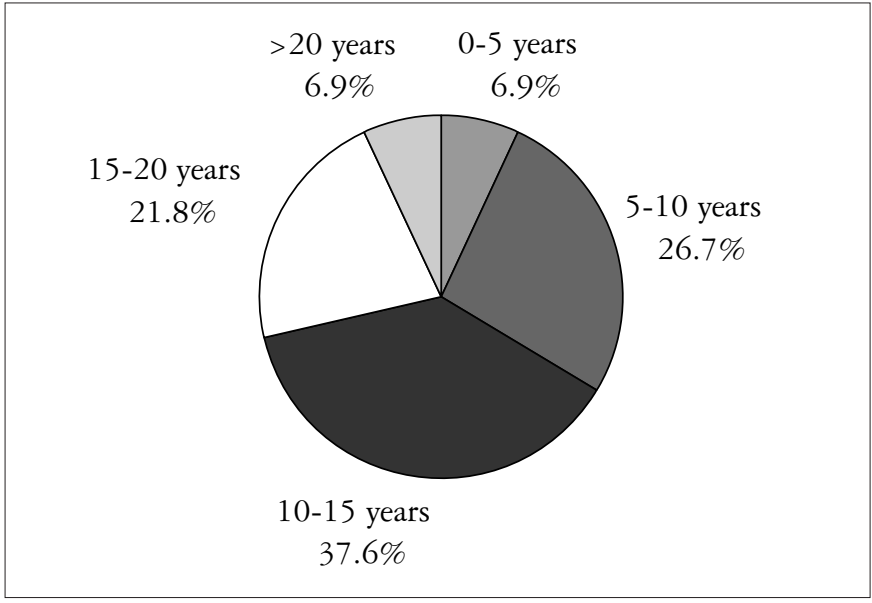

$0-5$ years $(n=7) ; 5-10$ years $(n=27) ; 10-15$ years $(n=38) ; 15-20$ years $(n=22) ;>20$ years $(n=7)$

FIGURE 2. Distribution of patients according to the age at diagnosis of cholelithiasis (percent versus age group)

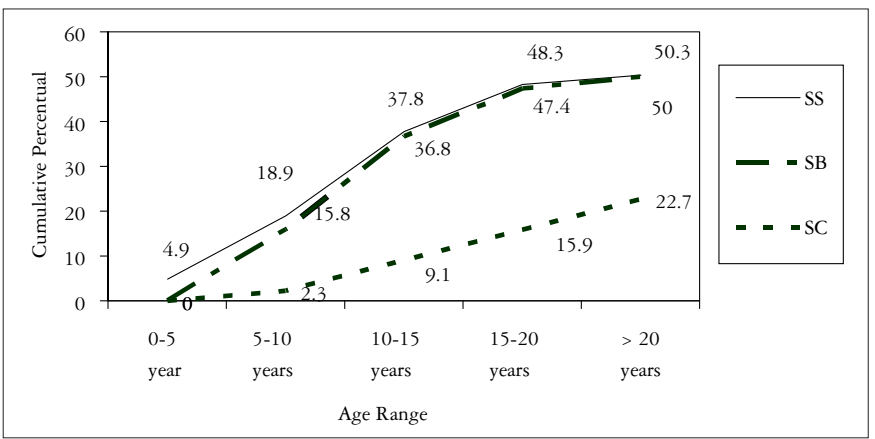

$\mathrm{Hb} \mathrm{SS}=$ sickle cell disease; $\mathrm{Hb} \mathrm{SB}=\mathrm{SB}$ thalassemia $; \mathrm{Hb} \mathrm{SC}=\mathrm{SC}$ disease

FIGURE 3. Cumulative percentage of the diagnosis of cholelithiasis according to type of hemoglobin

TABLE 2. Symptoms related to cholelithiasis

\begin{tabular}{lcc}
\hline Symptom $(\mathrm{n}=48)$ & $\mathrm{n}$ & $\%$ \\
\hline Abdominal pain & 45 & 93.1 \\
Vomiting & 16 & 32.7 \\
Nausea & 10 & 20.7 \\
Worsening of jaundice & 8 & 17.2 \\
Fever & 3 & 5.2 \\
Postmeal fullness & 2 & 3.5 \\
Others & 5 & 10.3 \\
\hline
\end{tabular}

TABLE 3. Characteristics of abdominal pain referred by SCD gallstones patients

\begin{tabular}{lccccc}
\hline $\begin{array}{l}\text { Location of } \\
\text { abdominal pain }(\mathrm{n}=45)\end{array}$ & $\mathrm{n}$ & $\%$ & $\begin{array}{c}\text { Type of abdominal pain } \\
(\mathbf{n}=45)\end{array}$ & $\mathrm{n}$ & $\%$ \\
\hline Right hypocondrium (RH) & 16 & 35.5 & Cholic/cramp & 13 & 27.8 \\
Difuse/inespecific & 11 & 24.5 & Others (heartbun, twinge) & 3 & 5.5 \\
Epigastric (E) & 8 & 17.8 & Inespecific/not described & 29 & 66.7 \\
RH + E & 5 & 11.1 & & & \\
Periumbilical & 2 & 4.4 & & & \\
Others & 3 & 6.6 & & & \\
\hline
\end{tabular}

In Figure 4, data regarding gallstone management are presented. Fifty-five patients $(54.5 \%)$ underwent cholecystectomy at a mean age of 14 years ( $\mathrm{SD}=5.4$, range: 4 to 30 years). Time interval between the diagnosis of cholelithiasis and surgical treatment was 1.8 years (median: 0.9 years). Fifty-five patients underwent cholecystectomy, 44 were symptomatic (80\%) and symptoms were relieved or disappeared after the procedure in 39. The main complaint was abdominal pain, but three patients reported no symptom relief after surgery. No data were available for two patients. Eleven (20.7\%) of 53 asymptomatic patients underwent surgery compared to $91.6 \%$ (44/48) of symptomatic patients. Asymptomatic patients and patients not submitted to surgery $(n=42)$ were followed up after the diagnosis of cholelithiasis for a period of 7 years $(\mathrm{SD}=4.8$ years) and none of the patients developed symptomatic gallbladder disease during this period.

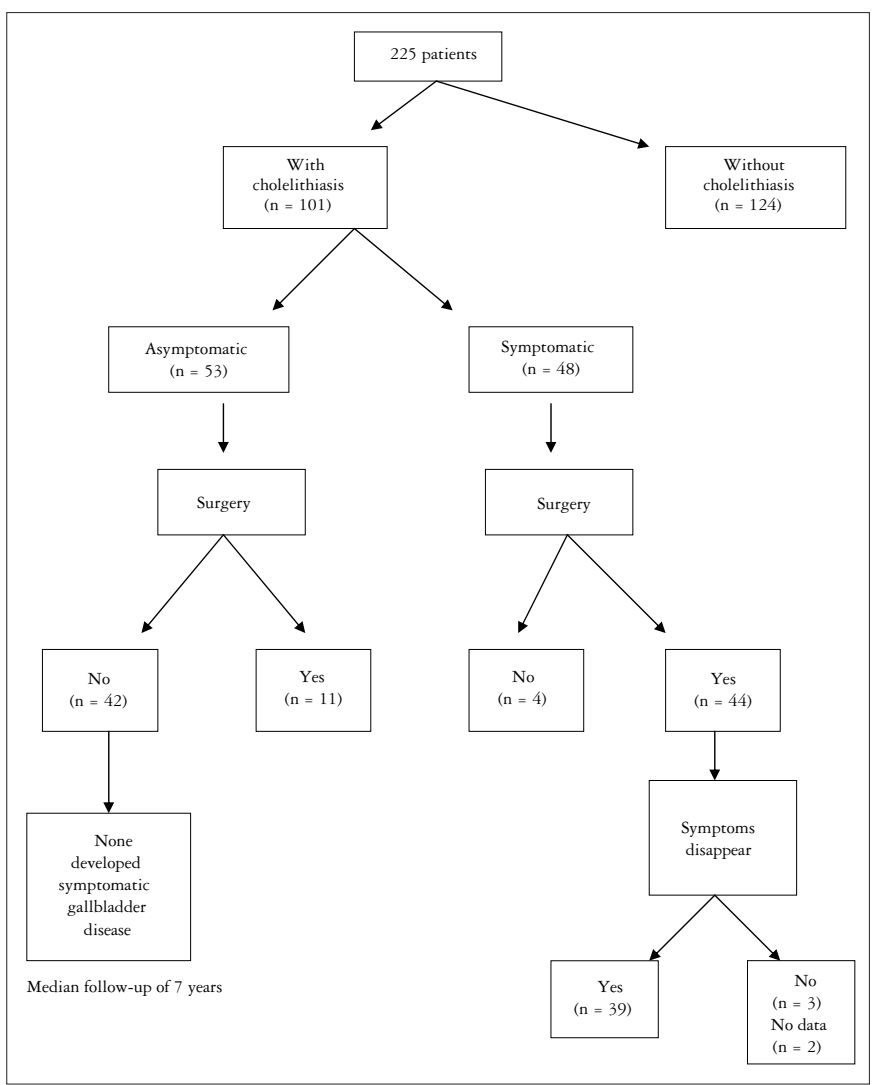

FIGURE 4. Analysis of ultrasound results and management of patients with sickle cell disease

The most common surgical technique was laparoscopy (74.5\%), with only 12 patients being submitted to laparotomy.

Postoperative data were recovered from 50 patients. There were 46 elective surgeries ( 9 with complications - 19,5\%) and 4 surgeries on emergency basis ( 2 with complications). Among the patients who underwent urgent surgery, only two were symptomatic at diagnosis of gallstones, and none of them had postoperative complications. There was no death, but the global 
morbidity rate was $22 \%$ (11 patients) and include gallbladder rupture, pneumonia, intra-abdominal bleeding, biliary fistula, and suture rupture. In Table 4 data of this patients with postoperative complications are presented.

TABLE 4. Postoperative course of patients undergone cholecystectomy and complications

\begin{tabular}{|c|c|c|c|c|}
\hline $\begin{array}{c}\text { Urgent } \\
\text { surgery } \\
\text { patients }\end{array}$ & $\begin{array}{c}\text { Symptom at } \\
\text { diagnosis of } \\
\text { gallstones }\end{array}$ & $\begin{array}{l}\text { Symptoms at } \\
\text { follow up }\end{array}$ & $\begin{array}{l}\text { Postoperative } \\
\text { complication }\end{array}$ & $\begin{array}{c}\text { Median hospital } \\
\text { stay (days) }\end{array}$ \\
\hline 1 & No & Yes & $\begin{array}{l}\text { Rupture of } \\
\text { gallbladder }\end{array}$ & 3 \\
\hline 2 & No & Yes & $\begin{array}{l}\text { Migration of } \\
\text { calculus }\end{array}$ & 6 \\
\hline \multicolumn{5}{|l|}{$\begin{array}{l}\text { Elective } \\
\text { surgery }\end{array}$} \\
\hline 1 & No & Yes & $\begin{array}{l}\text { Abdominal } \\
\text { haematoma }\end{array}$ & 2 \\
\hline 2 & No & Yes & $\begin{array}{c}\text { Pneumonia }+ \\
\text { pleural effusion }\end{array}$ & 11 \\
\hline 3 & No & Yes & $\begin{array}{l}\text { Rupture of } \\
\text { gallbladder }\end{array}$ & 3 \\
\hline 4 & No & Yes & $\begin{array}{l}\text { Rupture of } \\
\text { gallbladder }\end{array}$ & 3 \\
\hline 5 & No & Yes & $\begin{array}{l}\text { Dehiscence of } \\
\text { surgical points }\end{array}$ & N.A \\
\hline 6 & Yes & Yes & $\begin{array}{l}\text { Rupture of } \\
\text { gallbladder }\end{array}$ & 1 \\
\hline 7 & No & No & Pneumonia & 12 \\
\hline 8 & No & Yes & $\begin{array}{l}\text { Rupture of } \\
\text { gallbladder + } \\
\text { pneumonia }\end{array}$ & 7 \\
\hline 9 & Yes & Yes & $\begin{array}{l}\text { Pneumonia + biliar } \\
\text { fistula + atelectasis }\end{array}$ & 16 \\
\hline
\end{tabular}

\section{DISCUSSION}

The frequency of gallstones in patients with SCD varies according to different studies ${ }^{(1,2,3,4,6,7,8,12,13)}$. The selection of distinct populations, different age ranges and the inclusion of mainly symptomatic patients may explain some differences, but most authors have reported high rates, usually higher than $50 \%$. In the present study, the frequency of patients with gallstones was $45 \%$, a prevalence justifying concern regarding the diagnosis and complications of cholelithiasis in the SCD population. Our frequency was similar to that reported by WALKER et al. ${ }^{(12)}$, who found a prevalence of cholelithiasis of $52.7 \%$ in SS disease and of $20 \%$ in patients with SC disease evaluated at the age of 23; however, that study did not include patients with Sß thalassemia. MALONE et al. ${ }^{(4)}$ identified a $40 \%$ frequency of lithiasis in adolescents with SCD, with $75 \%$ of them being symptomatic. NZEH et al. ${ }^{(6)}$ reported a lower prevalence of $4.2 \%$, but the age range of the sample differed from that of the present series since patients from 2 months to 16 years were included, with the youngest patient being diagnosed with cholelithiasis at the age of 10 .

Analysis of the age at diagnosis of cholelithiasis showed that our data differed from those reported in the studies of SUELL et al. ${ }^{(10)}$ and WALKER et al. ${ }^{(12)}$ in which $15 \%$ of the patients were diagnosed before the age of 10 . In the present study, one-third of SCD patients were diagnosed between 5 and 10 years, with
$7 \%$ being diagnosed before the age of 5 and $27 \%$ between 5 and 10 years. In the study of NZEH et al. ${ }^{(6)}$, the youngest patient diagnosed with cholelithiasis was 10 years old and the patient diagnosed with biliary sludge was 5 years old.

Available data indicate the need for prospective assessment to evaluate the usefulness of an ultrasound screening program for children, especially above the age of 5 . Pediatricians should be advised to suspect gallstones in patients with SCD even before the age of 10 , especially if suggestive symptoms are present or in populations with a high prevalence of the homozygous hemoglobin SS genotype. Dietary and environmental factors other than those related to haplotypes and severe forms of SCD may explain the high incidence within the youngest age range.

PASSON et al. ${ }^{(9)}$ found that the uridine diphosphate (UDP)glucuronosyltransferase 1A (UGT1A) genotype is correlated with the development of gallstones in SCD patients. Unfortunately, we were unable to determine the presence of the UGT1A genotype in our study. Polymorphisms may explain differences between literature series.

In the present study, the percentage of asymptomatic patients with gallstones reached $51 \%$, in agreement with PAREZ et al. ${ }^{(8)}$ who reported $54 \%$ of patients without symptoms. Controversy still exists regarding the natural history of cholelithiasis in pediatric patients, especially those with SCD. WALKER et al. ${ }^{(12)}$ followed up patients for 25 years and found a large number of asymptomatic patients and a low $7 \%$ proportion of surgical indications. On the other hand, PAREZ et al. ${ }^{(8)}$ found $14 \%$ of cholelithiasis carriers in the age range from 0 to 18 years and $46 \%$ symptomatic patients, all of them undergoing cholecystectomy because of symptoms or even to prevent complications. The U. S. National Institutes of Health ${ }^{(5)}$ stated that there are sufficient data in the medical literature to indicate a non-surgical approach to asymptomatic patients, but there is still marked controversy.

SUELL et al. ${ }^{(10)}$ retrospectively evaluated 146 patients, 83 presenting lithiasis and 25 being asymptomatic. Among the latter, surgery was indicated in $60 \%$ of cases versus $67 \%$ in the symptomatic group. However, in the original "symptomatic" group, $25 \%$ of the patients had their symptoms relieved without surgery or any other treatment.

The attribution of a clinical symptom to cholelithiasis is quite difficult, especially in patients with SCD. Since abdominal pain is the most frequent symptom, one should keep in mind the large number of differential diagnoses, including those intrinsic to a hemolytic disease such as hepatic crises, vaso-occlusive crises, splenic sequestration, pancreatitis and others, and those not specifically associated with the SCD population such as intestinal parasitosis, urinary infection, peptic disease and intestinal constipation. In the present study, recurrent abdominal pain was the most frequent clinical symptom, occurring in $25 \%$ of patients.

Patients with SS and Sß thalassemia are recognized based on clinical severity and the intensity of hemolysis and this explains higher frequency of gallstones in these patients, when compared to patients with SC disease. Before the implantation of neonatal screening for hemoglobinopathy, patients with SC disease were diagnosed later than those with SS and Sß disease because of the oligosymptomatic clinical course. 
We found a morbidity rate of $22 \%$ in SCD children undergone cholecystectomy and a higher rate was seen in patients undergone urgent surgery. Asymptomatic patients at diagnosis of gallstones and whom became symptomatic at follow up usually did not need urgent surgery.

Asymptomatic patients followed in a conservative basis during a 7-year period did not presented symptomatic gallbladder. Despite there are no consensus in literature, according present data, conservative management was a good decision for SCD patients with asymptomatic cholelithiasis.

Besides cholecystectomy had a $22 \%$ morbidity rate, the majority of symptomatic patients referred relief or disappearing of their symptoms after the procedure. Abdominal pain continued to be observed in three patients, probably because in these cases gallstones were not the cause of the symptom. In two cases, data were not available because patients did not return to follow up.

Prospective studies to establish management protocols and the best moment to indicate surgery, in asymptomatic patients, through ultrasound screening for SCD and gallstones patients are required.

\section{CONCLUSIONS}

The frequency of cholelithiasis in children and adolescents with SCD at a Brazilian Center was $45 \%$; about $50 \%$ of patients with gallstones were asymptomatic and abdominal pain was the most frequent complaint in symptomatic patients (93\%). Clinical improvement after cholecystectomy was observed in 39/42 patients (93\%). Patients with SS or Sß disease were at a higher risk for the development of cholelithiasis compared to patients with SC disease. One-third of the patients were diagnosed before the age of 10. Our results indicate the need for prospective assessment to evaluate the usefulness of an ultrasound screening program in pediatric patients, especially after the age of 5 . We consider it to be important to suspect gallstones in SCD patients even before the age of 10, especially in the presence of suggestive symptoms and a high prevalence of the homozygous hemoglobin SS genotype.

Cholecystectomy must be considered in symptomatic patients. In asymptomatic patients, conservative management seems to be the better choice.

Gumiero APS, Bellomo-Brandão MA, Costa-Pinto EAL. Litíase biliar em crianças com doença falciforme acompanhadas em um centro de hematologia no Brasil. Arq Gastroenterol. 2008;45(4):313-8.

RESUMO - Racional - A doença falciforme causa hemólise crônica e acelerada que é reconhecida como fator de risco para desenvolvimento de colelitíase. Essa complicação pode ocorrer em mais de $50 \%$ da população adulta com doença falciforme. A colecistectomia é a conduta consensual para pacientes sintomáticos, mas nos assintomáticos a sua indicação é controversa. Objetivos - Verificar a prevalência de colelitíase em pacientes com doença falciforme e descrever a conduta tomada em caso de diagnóstico da complicação, numa corte de pacientes seguidos num centro terciário de hematologia pediátrica. Métodos - Neste estudo descritivo e retrospectivo, foram revistos prontuários de 225 pacientes e os dados relacionados à evolução clínica desses indivíduos foram registrados. Resultados - A freqüência cumulativa de colelitíase foi de $45 \%$, sendo que metade deles não apresentava quaisquer sintomas. As médias de idade ao diagnóstico de colelitíase e seu tratamento cirúrgico foram, respectivamente, 12,5 anos (desvio padrão $=5$ anos) e 14 anos (desvio padrão $=5,4$ anos). A prevalência de colelitíase foi maior nos pacientes com doença SS (homozigotos) e S $\beta$ (heterozigotos) talassemia, comparados aos pacientes com doença falciforme. Entre os pacientes sintomáticos (50\%), a dor abdominal inespecífica foi o único sintoma ou o sintoma predominante. Entre pacientes que realizaram colecistectomia $(n=44), 39$ tiveram melhora ou resolução de seus sintomas após o procedimento. Em 7 anos (desvio padrão = 4,8 anos) de seguimento clínico dos pacientes assintomáticos e não tratados cirurgicamente, verificou-se que nenhuma criança apresentou complicações relacionadas à colelitíase. Conclusões - A freqüência de colelitíase na população estudada foi de $45 \%$. Um terço dos pacientes foram diagnosticados antes dos 10 anos de idade. Pacientes com fenótipos SS (homozigotos) e S (heterozigotos) associaram-se a maior risco de litíase biliar, quando comparados aos pacientes com doença falciforme. Cerca de $50 \%$ dos pacientes com colelitíase era assintomática, a maioria não foi tratada cirurgicamente e não apresentou complicações relacionadas durante o período de seguimento de 7 anos. A colecistectomia deve ser considerada em pacientes sintomáticos. Em assintomáticos, o manejo conservador parece ser a melhor escolha.

DESCRITORES - Colelitíase. Doença da hemoglobina SC. Colecistectomia. Criança. 


\section{REFERENCES}

1. Al-Salem AH, Qaisruddin S. The significance of biliary sludge in children with sickle cell disease. Pediatr Surg Int. 1998;13;14-6.

2. Al-Salem AH. Should Cholecystectomy be performed concomitantly with splenectomy in children with sickle cell disease? Pediatr Surg Int. 2003;19:71-4.

3. Billa RF, Biwole MS, Juimo AG, Bejanga BI, Blackett K. Gallstone disease in African patients with sickle cell anemia: a preliminary report from Yaounde, Cameroon. Gut. 1991;32:539-41.

4. Malone BS, Werlin SL. Cholecystectomy and cholelithiasis in sickle cell anemia. Am J Dis Child. 1988;142:799-800.

5. National Institutes of Health. The management of sickle cell disease 2002, 111-112. Accessed June 25, 2005. Available at http://www.nhlbi.nih.gov/health/prof/blood/ sickle/index.htm.

6. Nzeh DA, Adedoyin MA. Sonographic pattern of gallbladder disease in children with sickle cell anemia. Pediatr Radiol. 1989;19:290-2.

7. Papadaki MG, Kattamis AC, Papadaki IG, Megas DG, Georgakopoulou TP, Mavrommati-Metaxotou A, Kattamis CA. Abdominal ultrasonographic findings in patients with sickle cell anemia and thalassaemia intermedia. Pediatr Radiol. $2003 ; 33: 515-21$.
8. Parez N, Quinet B, Batut S, Grimprel E, Larroquet M, Audry G, Begue P. Cholelithiasis in children with sickle cell disease: experience of a French pediatric hospital. Arch Pediatr. 2001;8:1045-9.

9. Passon RG, Howard TA, Zimmerman SA, Schultz WH, Ware RE. Influence of bilirubin uridine diphosphate-glucuronosyltransferase 1A promoter polymorphisms on serum bilirubin levels and cholelithiasis in children with sickle cell anemia. J Pediatr Hematol Oncol. 2001;23:448-51.

10. Suell MN, Horton TM, Dishop MK, Mahoney DH, Olutoye OO, Mueller BU. Outcomes for children with gallbladder abnormalities and sickle cell disease. J Pediatr. 2004;145:617-21.

11. Walker TM, Serjeant GR. Biliary sludge in sickle cell disease. J Pediatr. 1996;129:443-5

12. Walker TM, Hambleton IR, Serjeant GR. Gallstones in sickle cell disease: observations from the Jamaican Cohort Study. J Pediatr. 2000;136:80-5.

13. Winter SS, Kinney TR, Ware RE. Gallbladder sludge in children with sickle cell disease. J Pediatr. 1994;125(5 Pt 1):747-9. 